purpose of client-attorney communication ${ }^{31}$ and that it was circulated only to agents concerned with direct forwarding to the attorney, the importance of full disclosure at trial would seem to dictate denial of the privilege. Categorization of agents' reports as either "in anticipation of litigation" or in the "regular course of business" 32 finds no analytical basis in the rationale of the privilege.

The confusion in the cases cannot be entirely attributed to the impropriety of the tests used. It is evident that the courts have not been given an adequate picture of the circumstances surrounding the reports sought to be protected. ${ }^{33}$ Since the burden of proof is on the proponent of the privilege, opposing counsel and the court should be diligent in requiring a clear showing that the claim of privilege is well founded. ${ }^{34}$

\title{
DISCLOSURE OF INVESTIGATIVE REPORTS UNDER SECTION 6(j) OF THE SELECTIVE SERVICE ACT-A POSTSCRIPT TO UNITED STATES v. NUGENT
}

In the conscription of men for military service under the Selective Service Act, Congress has provided for the exemption of several classes of registrants. Among those exempted are conscientious objectors, persons whose religious beliefs do not permit them to serve in the armed forces. The task of separating valid from fraudulent claims for exemption has been committed to the selective service boards, local and appellate, as part of their general classificatory function under the Act. Normally, there is no resort to agencies outside the selective

${ }^{31}$ See, e.g., Atlantic Coast Line R. Co. v. Williams, 21 Ga. App. 453, 94 S.E. 584 (1917); Thomson v. Maryland Casualty Co., 11 Ont. L. Rep. 44, 45 (1906).

32 Although an accident report required by a corporation may not meet the regular-courseof-business standard for business-entry statutes, this should not imply that they cannot be in the "regular course of business" if that test is used in applying the privilege. It is clearly of general concern and in the best interests of a corporation to discover the nature and cause of accidents. Although in Carlton v. Western \& A. R. Co., 81 Ga. 531, 7 S.E. 623 (1888), the request for production was denied on other grounds, the court said: "We do not understand such a report to be a privileged communication. It seems that it was a report which the company, by its rules, required the conductor to make where a party was injured . . . a very good rule for the protection of the company and the employee." Ibid., at 534 and 625 . Compare Palmer v. Hoffman, 318 U.S. 109 (1943), with Pekelis v. Transcontinental \& Western Air, Inc., 187 F. 2d 122 (C.A. 2d, 1951).

${ }^{33} J u d g e$ Freed described this problem: "One of the chief difficulties which the courts face in deciding questions involving privileged communications . . . arises from the fact that they are seldom fully apprised of the circumstances under which those communications came into existence. When was the communication made? To whom and by whom was it made? ... What was the relation of the party giving or the party taking the statement to the defendant? How and when did the statement come into the hands of defendant's counsel? Is counsel a salaried employee of the party opposing discovery or is he an independent attorney merely retained by defendant? In any given case each of these questions may be of vital importance in determining whether or not the matters sought are actually privileged." Humphries v. Pennsylvania R. Co., 14 F.R.D. 177, 178 (N.D. Ohio, 1953).

${ }^{34}$ See Robertson v. Commonwealth, 181 Va. 520, 25 S.E. $2 d 352$ (1943). A voir dire is a form of proceeding well designed to reach such results. 
service system, but in conscientious-objector cases Congress has provided for a hearing before the Department of Justice as a guide to decision. The procedure for determining the "character and good faith" of registrants is set forth in Section 6(j) of the Selective Service Act. ${ }^{1}$ Upon the filing of an appeal from the decision of a local draft board, the appeal board refers the claim to the Department of Justice for inquiry and hearing; the Department of Justice then makes a recommendation which the appeal board is to consider, but need not -follow. It has been the practice of the Department of Justice to employ the F.B.I. to make an investigation into the background of each claimant as a preliminary to the hearing. Although the investigative report is placed before the Department of Justice hearing officer, it is not made available for examination by the registrant. The registrant is permitted to introduce evidence in his own behalf, but is unable to counter specific charges contained in the F.B.I. report. Upon request, however, the hearing officer will "advise the registrant as to the general nature and character of any evidence in his possession which is unfavorable to, and tends to defeat, the claim of the registrant. . .."2

In United States v. Nugent, ${ }^{3}$ a conscientious objector, under prosecution for failure to submit to induction, challenged the unfavorable classification of his appeal board. He argued that the decision of the appeal board was necessarily arbitrary ${ }^{4}$ because the failure to produce the F.B.I. report made it impossible for him to meet adverse evidence, and contended that this procedure violated his constitutional right to due process. The Supreme Court held that the Fifth Amendment does not require Congress, in the exercise of its war power, to provide hearings for registrants who wish to challenge their classification under the Selective Service Act. The Court further held, in interpreting Section 6(j), that

1 "Nothing contained in this title shall be construed to require any person to be subject to combatant training and service in the armed forces of the United States who, by reason of religious training and belief, is conscientiously opposed to participation in war in any form.... Any person claiming exemption from combatant training and service because of such conscientious objections shall, if such claim is not sustained by the local board, be entitled to an appeal to the appropriate appeal board. Upon the filing of such appeal, the appeal board shall refer any such claim to the Department of Justice for inquiry and hearing. The Department of Justice, after appropriate inquiry, shall hold a hearing with respect to the character and good faith of the objections of the persons concerned. . . The appeal board shall, in making its decision, give consideration to, but shall not be bound to follow, the recommendation of the Department of Justice together with the record on appeal from the local board." 65 Stat. 83 (1951), 50 U.S.C.A. App. \& 456(j) (Supp., 1953).

2 Instructions to Registrants Whose Claims for Exemption as Conscientious Objectors Have Been Appealed (a letter sent to appealing registrants from the office of the Attorney General).

8346 U.S. 1 (1953).

1 The Supreme Court held, in Falbo v. United States, 320 U.S. 549 (1944), that the determinations of selective service boards were not open to judicial review. This position was qualified in Estep v. United States, 327 U.S. 114 (1946), where it was held that the courts could intervene where the draft board had acted without jurisdiction. "The question of jurisdiction of the local board," the Court said, "is reached only if there is no basis in fact for the classification which it gave the registrant." (Emphasis supplied.) In Dickinson v. United States, 346 U.S. 389 (1953), the Court declared invalid a classification denying exemption where no evifence to support the classification had been introduced. 
Congress in establishing an advisory "inquiry and hearing" did not intend the formalities of a trial to be adhered to in these proceedings. " "It has regularly been assumed," the majority declared, "that it is not the function of this auxiliary procedure to provide a full-scale trial for each appealing registrant."." Three Justices dissented, however, protesting that "[t]he very purpose of a hearing is to give registrants an opportunity to meet adverse evidence. It makes a mockery of that purpose to suggest that such adverse evidence can be effectively met if its provenance be unknown."7 The dissenters relied heavily on language from decisions in the Second Circuit; the division within the Supreme Court reflected a sharp conflict among the lower courts.

In four cases, courts within the Second Circuit had upheld the right of registrants to examine F.B.I. reports. In United States v. Oller, ${ }^{8}$ the District Court for Connecticut held that the use of the reports by the hearing officer in making his recommendation without producing them for inspection was prejudicial to the registrants; the court entered a judgment of acquittal on charges of draft evasion. A similar result was reached by Chief Judge Hincks of that court in United States v. Geyer; ${ }^{9}$ in a passage cited at length by the Nugent dissenters he interpreted Section $6(j)$ as follows: "The natural import of the provision is, I think, that the investigative report resulting from the inquiry shall be made a part of the record for consideration by all directly concerned with the classification. ... Only if the Act be [so] construed . . . is the 'system of selection ... fair and just' within our Anglo-Saxon concepts of justice and due process."10 The Nugent case and its companion in the Supreme Court, United States v. Packer, also arose in the Second Circuit." After the district courts had entered convictions in these cases the court of appeals reversed, holding that under the statute, as interpreted in Geyer, registrants were entitled to examine the reports at the Department of Justice hearing. In the Packer case the court extended this right to a situation in which the report contained no findings unfavorable to the registrant.

On the other hand, the Sixth Circuit in Imboden v. United States ${ }^{12}$ held that where the registrant was given a letter outlining the adverse evidence, refusal to disclose the names of the informants did not deprive him of due process. Sub"Defendants in the Nugent case had failed to request summaries of "the general nature and
character" of unfavorable evidence, which the Department of Justice was willing to make
available. The Court held that the right to available. The Court held that the right to such summaries was waived by the failure to request
them.

6 United States v. Nugent, 346 U.S. 1, 9 (1953).

' Ibid., at 13.

8107 F. Supp. 54 (D. Conn., 1952).

108 F. Supp. 70 (D. Conn., 1952). $\quad 10$ Ibid, at 71 and 72.

11 United States v. Nugent, 200 F. $2 d 46$ (C.A. 2d, 1952); United States v. Packer, 200 F.
540 (C.A. 2d, 1952).

12194 F. 2d 508 (C.A. 6th, 1952). 
sequently, the Ninth Circuit in Elder v. United States ${ }^{13}$ took express exception to the Second Circuit's construction of Section 6(j) in the Nugent case, requiring complete disclosure of the report. In the Ninth Circuit's view, disclosure would frustrate the purpose of the Act by closing off the F.B.I.'s sources of information.

The Supreme Court in Nugent and Packer reversed the Second Circuit, but did not deny entirely the right of a registrant to be appraised of adverse charges contained in the F.B.I. report:

We think the Department of Justice satisfies its duties under $\$ 6(j)$ when it accords a fair opportunity to the registrant to speak his piece before an impartial hearing officer; when it permits him to produce all relevant evidence in his own behalf and at the same time supplies him with a fair résumé of any adverse evidence in the investigator's report. ${ }^{14}$

The recommendations of the Department of Justice can never be attacked as being without basis in fact because of a refusal to produce the F.B.I. reports. ${ }^{15}$ But the department is bound by the Nugent opinion to make available upon claimant's request a fair résumé of testimony against him; adherence to this procedure was seen by the court to be "an important and delicate" responsibility. The $N u g e n t$ case thus achieves a result halfway between full disclosure and complete denial of the opportunity to answer adverse information.

Generally, courts since the Nugent decision have followed it in dismissing summarily due process objections concerning the use of secret reports, the refusal to produce such reports and the failure to provide a "fair résumé" when not requested at the hearing. ${ }^{16}$ However, in a very recent decision, the Fourth Circuit Court of Appeals set aside a conviction where the complete F.B.I. report had mistakenly been submitted to the draft boards, but was not made available to the registrant. ${ }^{17}$

The major problem left open by the Nugent case arises when a registrant challenges the fairness of the résumé which he received. The District Court for New Jersey upon examination of a Department of Justice letter summarizing

13202 F. $2 d 465$ (C.A. 9th, 1953).

14 United States v. Nugent, 346 U.S. 1, 6 (1953).

${ }^{15}$ The Nugent case thus seems to overrule United States v. Bouziden, 108 F. Supp. 395 (W.D. Okla., 1952). That court stated: "The hearing officer must not be permitted to withhold unfavorable information gained during the inquiry, and giving no opportunity to rebut at the hearing, then use this same unfavorable information as a basis for his adverse advisory recommendation." Compare United States v. Annett, 108 F. Supp. 400 (W.D. Okla., 1952) and United States v. Everngam, 102 F. Supp. 128 (S.D. W.Va., 1951).

${ }^{6}$ Bejelis v. United States, 206 F. 2d 354 (C.A. 6th, 1953); United States v. Borisuk, 206 F. 2d 338 (C.A. 3d, 1953); United States v. Gray, 207 F. 2d 237 (C.A. 9th, 1953); United States v. Dal Santo, 205 F. 2 d 429 (C.A. 7th, 1953), cert. denied, 346 U.S. 858 (1953); United States v. Gonzales, 120 F. Supp. 730 (E.D. Mich., 1953).

${ }_{17}$ Brewer v. United States, 211 F. 2d 864 (C.A. 4th, 1954). The Court declared that where "the Local and Appeal Boards have had ready access to the actual F.B.I. file, and where their final classification of registrant is assumedly based upon information contained therein, to deny the registrant equal access to the evidence upon which his case is determined is to reject our most basic concept of due process." While this case will probably prove to be unique on its facts, it is perhaps indicative of a reluctance to extend Nugent beyond its own facts. 
the representations made against the registrant held that it was sufficient, although it did not disclose the names of witnesses. ${ }^{18}$ But in the Second Circuit the courts have regarded the determination of sufficiency as a means of providing registrants with the opportunity to examine at trial the investigative reports withheld at the hearing.

In United States v. Evans, ${ }^{19}$ Judge Hincks said:

It is my opinion that I cannot conscientiously determine that the résumé was fair without an opportunity to inspect the investigative report of which it is claimed to be a résumé.... Even if the résumé given be deemed presumptively fair, on trial the registrant must be allowed to combat the presumption by the only means possible,comparison with the investigative report itself.20

The prosecution contended that the Nugent opinion justified their withholding the reports. The court, however, held that the force of the Nugent decision was directed to the level of the departmental hearing only, ${ }^{21}$ and had no effect on the right of a court to subpoena relevant documents. Once the government chose to prosecute for draft evasion, they were bound under the doctrine of United States v. Andolscheck ${ }^{22}$ to produce all documents relating to the crime.

In the most recent case under Section $6(\mathrm{j})$, United States v. Stasevic, ${ }^{23}$ the Southern District of New York in ruling on prosecution motions to quash subpoenas for the production of F.B.I. reports gave a similar interpretation to the Nugent case. One defendant, who had not waived his right to obtain the résumé of the investigative report had nevertheless been denied access to it. ${ }^{24}$ Under Nugent this defendant was entitled to the résume if it contained any adverse evidence; and the court declared that without production of the report the nature of its contents could not be determined. The court denied the motion

${ }_{18}$ United States ex rel. Berman v. Craig, 115 F. Supp. 6 (D. N. J., 1953).

19115 F. Supp. 340 (D. Conn., 1953).

${ }^{20}$ Ibid., at 343. Accord: United States v. Edmiston, 118 F. Supp. 238 (D. Neb., 1954); United States v. Stull (E.D. Va. Nov. 1953) (not reported).

21. The Brewer case, note 17 supra, in refusing to apply the Nugent holding to proceedings before the local and appellate draft boards, is in accord with this view.

${ }^{22} 142$ F. 2d 503 (C.A. 2d, 1944). The court said: "While we must accept it as lawful for a department of the government to suppress documents ... [so] far as they directly touch the criminal dealings, the prosecution necessarily ends any confidential character the documents may possess. ... The government must choose; either it must leave the transactions in the obscurity from which a trial will draw them, or it must expose them fully." Ibid., at 506.

The Andolscheck doctrine has been recognized in the Supreme Court by implication in denying discovery of confidential government documents in cases other than criminal prosecutions by the government. United States v. Reynolds, 345 U.S. 1, 12 (1953) (action against the govermment under the Federal Tort Claims Act); United States ex rel. Touhy v. Ragen, 340 U.S. 462,467 (1951) (habeas corpus proceeding by prisoner challenging constitutionality of state conviction).

${ }^{23} 117$ F. Supp. 371 (S.D. N.Y., 1953).

${ }_{21}$ Motions were made against three separate defendants. All of the defendants had been denied résumés of unfavorable evidence. Two of the defendants, however, had failed to request such résumés, and, under the reasoning of the Nugent case, waived their rights to them. Ibid., at 374. The third defendant, Prytyskacz, unlike the others, did not receive a letter informing him of his right to request a résume. 
to quash the subpoena for the report on this defendant, and ruled further that upon its production it would be open to inspection by his counsel as well as by the court.

The effect of the reading given the Supreme Court's Nugent opinion by Second Circuit courts is to bring the investigative report before the court in almost every prosecution of conscientious objectors for failure to submit to induction. If the refusal to produce the reports at the hearing stems from a desire to keep -them confidential, these decisions obstruct this purpose. The need for secrecy has generally been considered to be the basis of the Nugent decision, and was the express rationale of the Ninth Circuit in arriving at the same result in Elder. ${ }^{25}$ But the Supreme Court made no mention of the importance of secrecy; it appears unlikely that the Court intended to exclude the reports at the trial without reference to the inroads such exclusion would make on the Andolschek doctrine. The Evans-Stasevic interpretation limiting the application of Nugent to the hearing level thus seems sound.

The language of the Nugent opinion would suggest rather that its goal was to facilitate the operation of a self-contained administrative process, in classification of registrants claiming exemption as conscientious objectors. Under some subsequent decisions, however, any delays caused by examination of the F.B.I. reports would be shifted to the trial stage, rather than eliminated altogether. As the dissent in Nugent urges, it was the intent of Congress in Section $6(j)$ that all evidence be heard by the hearing officer. The provision for a hearing for conscientious objectors would seem to have been caused at least in part by a desire to avoid the harshness of a system which would require registrants to risk imprisonment if they wished effectively to challenge their classification. Paradoxically, then, the $N$ ugent opinion, by leaving consideration of investigative reports to the courts, has nullified the major purpose of the decision, to maintain an independent and efficient selective service system; by extending the hope of reclassification to registrants, it may, contrary to the purpose of Section $6(j)$, cause many to risk imprisonment as draft evaders in order to obtain a conclusive determination of the elusive questions of fact which necessarily arise in the classification of conscientious objectors. The position of the $N u g e n t$ dissenters has therefore been vindicated at least in some degree by later developments. But given the majority holding, the gloss placed on the case by the courts in the Second Circuit is preferable to the result which would obtain if the decision were followed to its logical extreme, the complete denial of access to the investigative reports. ${ }^{26}$

${ }^{25}$ "If the agency inquiry . . . is to be productive of worthwhile results it seems essential that frankness on the part of persons interviewed be encouraged by assurance that their identity will not be divulged; and in the absence of clear intimation in the statute to the contrary the court will not assume that Congress intended these reports to be made public." Elder v. United States, 202 F. 2d 465, 469 (C.A. 9th, 1953).

${ }^{20}$ Since this comment went to press, the Seventh Circuit Court of Appeals in a considered opinion specifically repudiated the Evans-Stasevic interpretation of the Nugent case. In this Court's view, not even a "fair résume" need be made available to the registrant. United States 